\title{
Geotechnical risk management at Teck Coal
}

\author{
A. Bidwell Teck Coal Ltd., Canada \\ A. Knight Teck Coal Ltd., Canada \\ W.S. Anderson Teck Resources Ltd., Canada
}

\begin{abstract}
The first standardised Geotechnical Assessment Process for identifying and assessing geotechnical risks at Teck Coal's open pit mining operations was developed and implemented in 2012. This work was started as a corporate initiative because Teck, as a publicly traded company, desired to demonstrate industry-best practices for managing geotechnical risks and to develop Teck Coal corporate geotechnical standards. Furthermore, corporate geotechnical standards and a consistently high level of geotechnical practice are required as part of the safe and profitable execution of the potential expansions at Teck Coal's operating sites and the possible development of additional mines.
\end{abstract}

This paper describes the three stage Geotechnical Assessment Process - the application of an assessment tool to scrutinise the geotechnical aspects of mine design, operation and closure, the categorisation and ranking of identified geotechnical risks, and the development of action plans to mitigate the risks. The assessment tool was developed in-house because there were no suitable published or publicly-available procedures. The risk categorisation and ranking procedure was adapted from the existing Teck stage gating process used for major projects. The ranked risks were grouped by common themes, and then used as the basis for developing site-specific 'Project Initiatives' that list actionable steps to ensure that each site's geotechnical systems and processes are aligned with Teck Coal's emerging standardised approach for identifying and managing the geotechnical risks at existing operations and for potential expansions.

\section{Introduction}

Teck Coal Limited, a division of Teck Resources Limited, operates six open pit coal mining operations in western Canada that collectively produce approximately $24 \mathrm{Mt}$ of steelmaking coal per year, primarily for export. Figure 1 illustrates the locations of Teck Coal's operating mines in the provinces of British Columbia and Alberta along with the locations of the export terminals that the majority of the produced coal is shipped through.

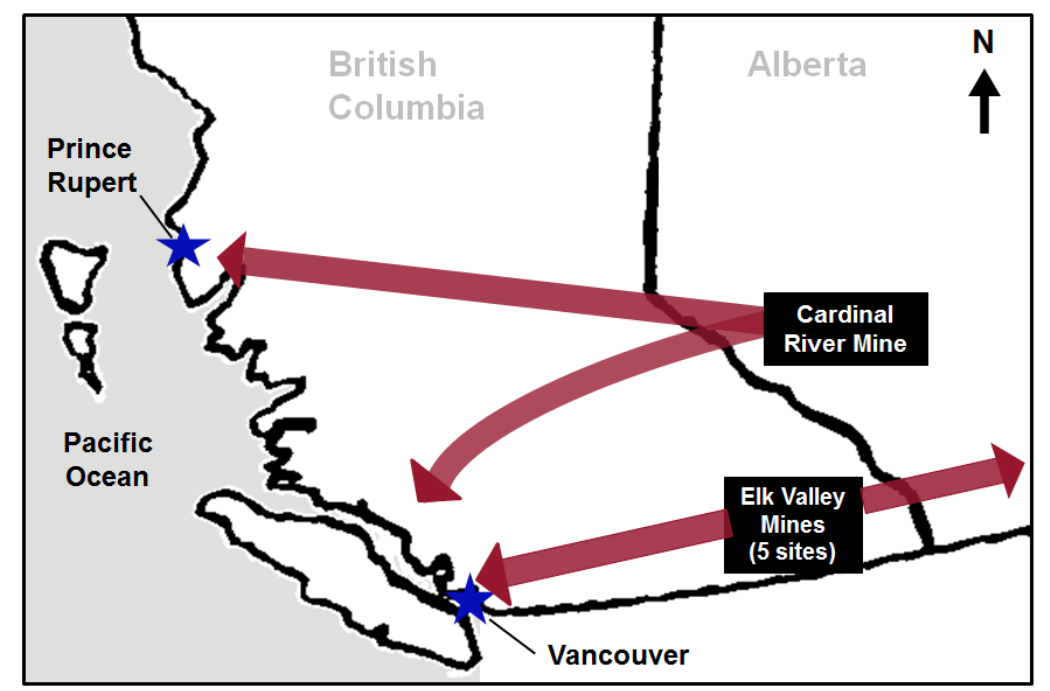

Figure 1 Teck Coal sites and main export terminals 
The majority of Teck Coal's mining operations are within the highly folded and faulted rocks of the front ranges of the Canadian Rocky Mountains. Open pit depths of up to approximately $400 \mathrm{~m}$ have been completed to date. Potential expansions at some of the operating sites could include pit depths of up to $800 \mathrm{~m}$ or more, and extend into areas with more complex geological and hydrogeological conditions than encountered to date. The external waste rock spoils at the sites are typically constructed as end-dumped, top-down constructed valley fills, and are among the largest in the world with planned volumes of up to several hundred million bcm and face heights of up to $400 \mathrm{~m}$. Experience with these spoils has contributed to the current state-of-practice for the design, monitoring and safe operation of large, ex-pit waste spoils in mountainous terrain (Eaton, 2000).

\section{$2 \quad$ History of geotechnical practice at Teck Coal}

Open pit mining operations at each of the six mines started at various times from the 1960s onwards. Over time, the sites were operated by a variety of private and publicly-held companies before coming together under common ownership in the early 2000s, and wholly owned by Teck Coal since 2008. Therefore, the geotechnical systems and practices at each of the sites were developed independently and reflected each site's individual development and operational history. As a result, the scope and level of geotechnical practice at each site, while generally appropriate for each site's individual needs, has not previously been linked to a clearly-defined set of corporate standards for identifying and managing geotechnical risk.

\section{The importance of geotechnical risk management}

Teck Coal requires a comprehensive and consistently high level of geotechnical practice to manage geotechnical risks for the following primary reasons:

- Teck's status as a publicly traded company requires that geotechnical risks be managed using industry-best practices.

- The challenging geotechnical aspects of some of the potential expansions at the operating sites.

- Geotechnical risks present a number of critical or catastrophic level hazards that have the potential to cause injuries or fatalities or contribute to substantial negative monetary impacts. Potential failure mechanisms and other issues that can cause significant geotechnical risks include pit wall instabilities (ranging from bench scale, inter-ramp scale, wall scale), lack of reconciliation of design inputs/assumptions with actual ground conditions and measured pit wall performance as mining progresses, issues with the performance of tailings dams and water impoundments, and unforeseen geotechnical issues and/or unforecast effort required for reclamation and closure of completed mining areas and waste rock spoils. Geotechnical incidents can also result in regulatory issues, and have the potential to damage the company's reputation and social licence to mine.

The importance of managing geotechnical risks was recognised; however, a systematic and comprehensive process to identify, assess and prioritise geotechnical risks on a multi-site basis was required in order to take this beyond a 'gut feeling' and confirm a business case for the required staff and resources to do so. Therefore, in 2012 Teck developed and implemented the Geotechnical Assessment Process that is described in the following sections. The Geotechnical Assessment Process was also considered to be worthwhile for the following secondary reasons:

- To facilitate an ongoing dialogue between the operating sites and the growing corporate engineering group on the scope of an effective geotechnical program for Teck Coal's operations and potential expansions.

- To raise the level of awareness of geotechnical issues, and develop a proactive culture that is focused on the prevention and early identification and control of potential geotechnical issues.

- To start to establish and maintain corporate geotechnical standards, along with a geotechnical community of practice within Teck Coal and Teck Resources overall. 


\section{$4 \quad$ Geotechnical Assessment Process}

\subsection{Description}

The Teck Coal Geotechnical Assessment Process has three stages:

1. The application of an assessment tool to identify geotechnical risks in the various aspects of design, operations and closure for an open pit coal mine.

2. The categorisation and ranking of the identified risks.

3. The development of a prioritised list of actions to mitigate these geotechnical risks.

\subsection{Assessment tool and identification of risks}

The assessment tool for Teck Coal's Geotechnical Assessment Process was developed in-house, after consideration of two published examples of similar processes and assessment tools:

- Hamman (2009) presents an example of a qualitative assessment procedure for the review of geotechnical management practices at mine sites. This procedure followed a 'checklist' methodology to facilitate a qualitative risk analysis and was of interest as an example of a due diligence exercise for corporate governance purposes.

- Dixon et al. (2011) presents an example of a risk based geotechnical slope reconciliation process implemented for Rio Tinto Iron Ore's Pilbara Operations. The process described is specific to pit slope risk management rather than a broader consideration of the various aspects of design, operations and closure. However, it was a valuable example of the application of a geotechnical risk assessment tool in the face of challenges due to a large number of operating pits at multiple sites, gaps in geotechnical knowledge, legacy issues from long-term operations, limited geotechnical resources and significant possible future expansions. These challenges are generally similar to Teck Coal's situation during the early stages of establishing corporate geotechnical standards and developing a corporate geotechnical community of practice.

- The development of a Teck Coal-specific assessment tool sought to build upon the key features of the two above-noted examples for a relatively broad review of the geotechnical aspects of the design, operations and closure of Teck Coal's mine sites. This was achieved by considering five areas of geotechnical practice, as listed in Table 1 (along with 'focusing questions' for each).

Table 1 Areas of geotechnical practice

\begin{tabular}{ll}
\hline Area of Geotechnical Practice & Focusing Question \\
\hline Personnel & $\begin{array}{l}\text { Do we have skilled and qualified personnel in place to support our } \\
\text { geotechnical, hydrogeological and hydrological activities? }\end{array}$ \\
Systems & $\begin{array}{l}\text { Do we have systems, processes and procedures in place to mitigate } \\
\text { the geotechnical risks? }\end{array}$ \\
$\begin{array}{ll}\text { Exploration, design and } & \text { Are we performing the appropriate level of geotechnical work? Are } \\
\text { long range planning } & \text { we linking the results to the designs in a timely manner? } \\
\text { Operations and monitoring } & \text { Do we understand our processes and procedures related to } \\
& \text { operations and monitoring and do we have the necessary checks in } \\
\text { place to verify that we are following the plan? }\end{array}$ \\
$\begin{array}{l}\text { Geotechnical requirements for } \\
\text { Dosure planning }\end{array}$ & $\begin{array}{l}\text { hydrological risks associated with closure and have we defined the } \\
\text { mitigation measures? }\end{array}$ \\
\hline
\end{tabular}


Each of these five areas of geotechnical practice was divided into a total of 70 distinct elements that could each be pinpointed for assessment. For each element, brief descriptions of six different levels of practice (non-compliant/not applicable, regulatory requirement/minimum practice, below average, above average, industry best practice, and leading practice/innovation opportunities) were developed. Tables 2 to 4 provide excerpts from three of the five 'Area of Geotechnical Practice' tables, which present these elements and level of practice descriptions. Please note that due to format requirements, Tables 2 to 4 include only selected elements and three of the five levels of practice descriptions.

When using the assessment tool, the current and target levels of geotechnical practice for each element are identified and brief descriptions of the details and context are recorded in the geotechnical practice tables. Any element for which the current level of practice is less than the mine's established target level of practice (i.e. there is a 'gap') represents a geotechnical risk that is assessed and ranked in the next stage of the Geotechnical Assessment Process. The number and severity of gaps between the current and target levels of geotechnical practice are visually summarised using radar plots for each of the five areas of geotechnical practice. Figure 2 presents an example of such a radar plot for the Systems area of geotechnical practice.

\section{SYSTEMS}

\section{(Processes \& Procedures In-place to Mitigate Risks)}

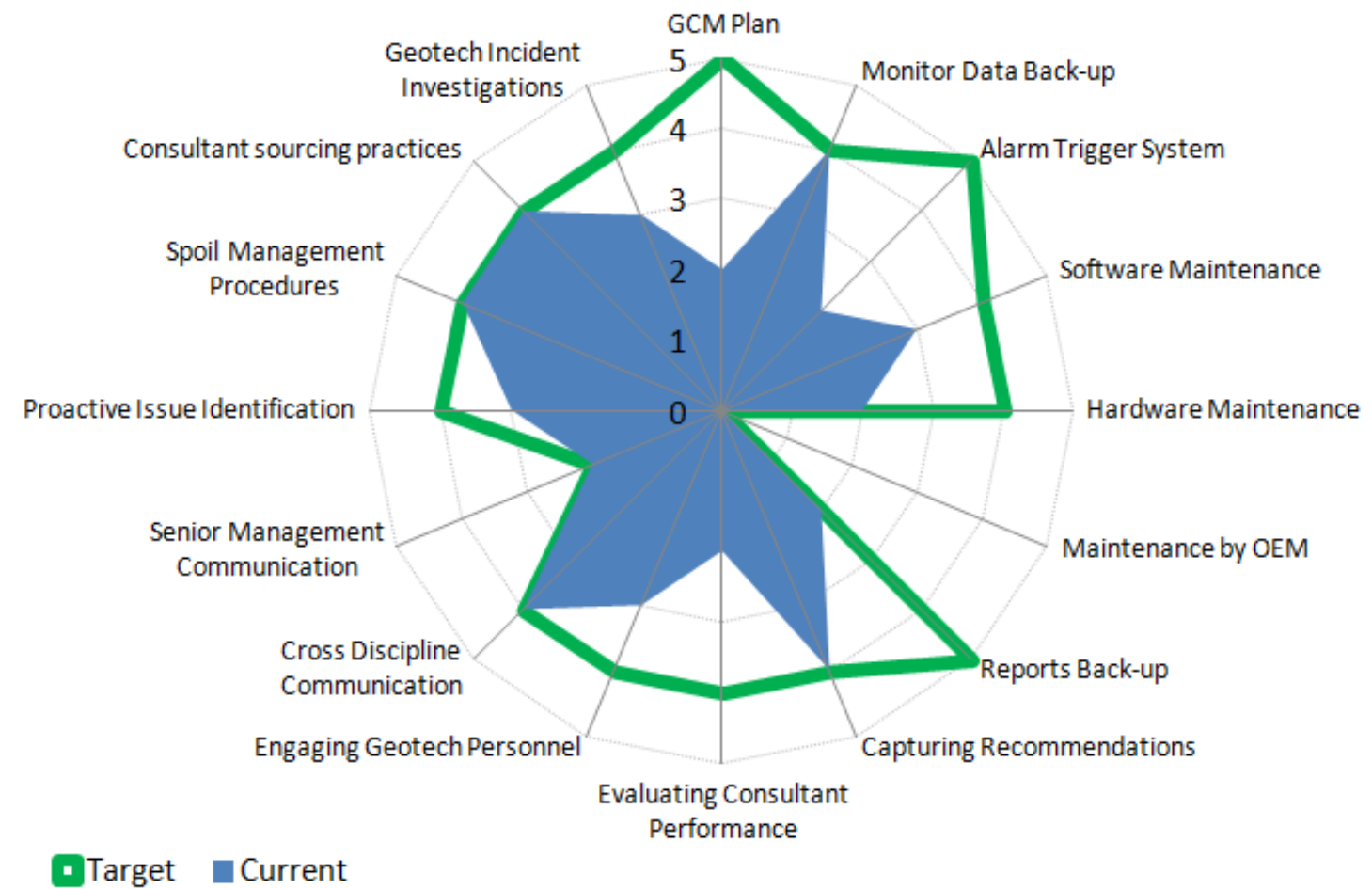

Figure 2 Example radar plot for the 'Systems' area of geotechnical practice

In addition to the radar plots by area of geotechnical practice, the elements within each area of geotechnical practice can also be illustrated with a second set of five radar plots that are generated by regrouping the elements by five engineering processes:

- Communication and integration - aspects of communication about geotechnical issues between different departments at a site or on a project.

- Engineering and modelling - engineering analysis and the preparation and application of geotechnical models. 


\section{Table 2 Excerpts from 'Personnel' area of geotechnical practice table}

\begin{tabular}{|c|c|c|c|c|}
\hline Element & Additional Context & $\begin{array}{l}\text { Regulatory Requirement/ } \\
\text { Minimum Practice }\end{array}$ & Above Average & Industry Best Practice \\
\hline $\begin{array}{l}\text { Availability of qualified personnel } \\
\text { for performing instrument } \\
\text { readings and routine inspections } \\
\text { within established monitoring } \\
\text { programs. }\end{array}$ & $\begin{array}{l}\text { Do the people taking instrument } \\
\text { readings and conducting } \\
\text { inspections understand the } \\
\text { purpose behind them and are they } \\
\text { familiar and experienced with the } \\
\text { practices? }\end{array}$ & $\begin{array}{l}\text { Monitoring and inspections } \\
\text { completed. Qualifications of } \\
\text { the personnel conducting this } \\
\text { work are not specified. }\end{array}$ & $\begin{array}{l}\text { Qualified personnel designated for } \\
\text { geotechnical tasks that are formally part of } \\
\text { their role. Geotechnical tasks usually given } \\
\text { priority and usually completed in a timely } \\
\text { manner. }\end{array}$ & $\begin{array}{l}\text { Full-time engineer or technician } \\
\text { available with geotechnical tasks } \\
\text { formally part of their role and as their } \\
\text { top priority. Tasks completed in a } \\
\text { timely manner and external } \\
\text { assistance from others is available } \\
\text { when needed. }\end{array}$ \\
\hline $\begin{array}{l}\text { Availability of qualified personnel } \\
\text { for geotechnical engineering role. }\end{array}$ & $\begin{array}{l}\text { Are there people at site with the } \\
\text { qualifications and training to carry } \\
\text { out geotechnical engineering } \\
\text { analysis? }\end{array}$ & $\begin{array}{l}\text { Professional registration with } \\
\text { APEGBC and/or APEGA. }\end{array}$ & $\begin{array}{l}\text { A specific person or persons identified as } \\
\text { responsible for geotechnical engineering } \\
\text { analysis in addition to other duties, with } \\
\text { geotechnical tasks usually given priority } \\
\text { and covered in a timely and ongoing } \\
\text { manner. }\end{array}$ & $\begin{array}{l}\text { Full-time geotechnical personnel } \\
\text { available and corporate resources } \\
\text { available for geotechnical support and } \\
\text { to identify and share best practices } \\
\text { between sites. }\end{array}$ \\
\hline $\begin{array}{l}\text { Availability of geotechnical } \\
\text { engineering personnel for } \\
\text { maintaining and updating the site } \\
\text { geotechnical model. }\end{array}$ & $\begin{array}{l}\text { Are there people at site with the } \\
\text { experience to develop and } \\
\text { maintain a geotechnical model and } \\
\text { is this work prioritised? }\end{array}$ & N/A & $\begin{array}{l}\text { Geotechnical personnel available to } \\
\text { sporadically update the geotechnical } \\
\text { model for expected critical areas. }\end{array}$ & $\begin{array}{l}\text { Geotechnical model maintained by } \\
\text { site geotechnical personnel. Any } \\
\text { updates to the model are reviewed } \\
\text { and vetted by authorised geotechnical } \\
\text { personnel. Specialist/external support } \\
\text { brought in when required (e.g. } \\
\text { structural geology, hydrogeology). }\end{array}$ \\
\hline $\begin{array}{l}\text { Expert-level guidance and review } \\
\text { (in house and/or consultants) on } \\
\text { geotechnical matters. Minimum } \\
\text { annual geotechnical review of key } \\
\text { facilities. }\end{array}$ & $\begin{array}{l}\text { How are we conducting 3rd party } \\
\text { audits of our practices and to } \\
\text { confirm our findings? }\end{array}$ & $\begin{array}{l}\text { Annual review of high risk } \\
\text { geotechnical facilities. }\end{array}$ & $\begin{array}{l}\text { Senior in-house and external review of the } \\
\text { majority of geotechnical facilities. }\end{array}$ & $\begin{array}{l}\text { Geotechnical review from in-house } \\
\text { principal-level geotechnical lead, peer } \\
\text { review from in-house geotechnical } \\
\text { personnel from other sites, timely } \\
\text { support from consultants when } \\
\text { required, and a world class external } \\
\text { Geotechnical Review Board that } \\
\text { meets regularly. }\end{array}$ \\
\hline $\begin{array}{l}\text { Assessment of geotechnical } \\
\text { staffing levels relative to workload } \\
\text { and required skills and experience. }\end{array}$ & $\begin{array}{l}\text { Do we have process in place to } \\
\text { look ahead at future staffing } \\
\text { requirements? }\end{array}$ & N/A & $\begin{array}{l}\text { Occasional or ad-hoc assessment of current } \\
\text { staffing levels and forecasting of needs. }\end{array}$ & $\begin{array}{l}\text { Bottom-up workload assessment for } \\
\text { all staff that includes all activities } \\
\text { performed throughout the course of a } \\
\text { 'normal' business year. Staffing levels } \\
\text { derived from business requirements } \\
\text { rather than financial objectives. }\end{array}$ \\
\hline
\end{tabular}


Table 3 Excerpts from 'Exploration, Design and Long Range Planning' area of geotechnical practice table

\begin{tabular}{|c|c|c|c|c|}
\hline Element & Additional Context & $\begin{array}{l}\text { Regulatory Requirement or } \\
\text { Minimum Practice }\end{array}$ & Above Average & Industry Best Practice \\
\hline $\begin{array}{l}\text { Pits - proactive geotechnical } \\
\text { and hydrogeological } \\
\text { investigations, both } \\
\text { pre-mining investigations and } \\
\text { supplementary investigation } \\
\text { work as warranted as mining } \\
\text { progresses. }\end{array}$ & $\begin{array}{l}\text { Are our geotechnical } \\
\text { investigation programs } \\
\text { timely, comprehensive, } \\
\text { proactive, and targeted at } \\
\text { specific features? }\end{array}$ & $\begin{array}{l}\text { Geotechnical and } \\
\text { hydrogeological investigation, } \\
\text { sufficient for regulatory approval } \\
\text { of project. }\end{array}$ & $\begin{array}{l}\text { Investigations, including instrument } \\
\text { installations, use appropriate geotechnical } \\
\text { and hydrogeological investigation methods } \\
\text { and at targeted locations (i.e. not simply } \\
\text { piggy-backed onto exploration drilling } \\
\text { locations). Investigations designed and } \\
\text { executed by a team of Teck and consultant } \\
\text { personnel. }\end{array}$ & $\begin{array}{l}\text { Comprehensive geotechnical and } \\
\text { hydrogeological investigation and } \\
\text { instrumentation program, consistent with } \\
\text { actions described in Table } 1.2 \text { of 'Guidelines } \\
\text { for Open Pit Slope Design' (Stacey, 2009). } \\
\text { Investigations designed and executed by a } \\
\text { team of Teck and consultant personnel and } \\
\text { vetted by Geotechnical Review Board prior to } \\
\text { execution. }\end{array}$ \\
\hline $\begin{array}{l}\text { Pits - reconciliation of } \\
\text { geotechnical and } \\
\text { hydrogeological models as } \\
\text { data becomes available from } \\
\text { operations and } \\
\text { supplementary investigation } \\
\text { work. }\end{array}$ & $\begin{array}{l}\text { Are geotechnical models } \\
\text { being reconciled and } \\
\text { updated in a timely manner } \\
\text { when new data becomes } \\
\text { available? }\end{array}$ & $\mathrm{N} / \mathrm{A}$ & $\begin{array}{l}\text { Formal reconciliation of the model for most } \\
\text { areas, usually in response to issues during } \\
\text { mining and occasionally in an effort to } \\
\text { calibrate the model with new/additional } \\
\text { data. }\end{array}$ & $\begin{array}{l}\text { Ongoing reconciliation of the model as } \\
\text { additional data becomes available. } \\
\text { Back-analysis using high quality monitoring } \\
\text { data and advanced modelling methods (e.g. } \\
\text { 3D analyses). }\end{array}$ \\
\hline $\begin{array}{l}\text { Spoils - proactive foundation } \\
\text { investigation and } \\
\text { characterisation of } \\
\text { foundation conditions. }\end{array}$ & $\begin{array}{l}\text { How are we investigating } \\
\text { the foundations of our } \\
\text { spoils before they are } \\
\text { built? }\end{array}$ & $\begin{array}{l}\text { Regulations stipulate 'good } \\
\text { engineering practice for design } \\
\text { by a qualified person', and } \\
\text { 'major dumps shall be designed } \\
\text { in accordance with the Interim } \\
\text { Guidelines of the BC Mine Waste } \\
\text { Rock Pile Research Committee } \\
\text { 1991'. }\end{array}$ & $\begin{array}{l}\text { Investigation of foundation conditions in the } \\
\text { spoil footprint using test pits/trenches and } \\
\text { some drilling and index testing of soil } \\
\text { samples to identify areas with weak/low } \\
\text { permeability soils. No instrument } \\
\text { installations. Moderate confidence models. }\end{array}$ & $\begin{array}{l}\text { Comprehensive investigation of foundation } \\
\text { conditions in the spoil footprint. Test } \\
\text { pits/trenches, borehole drilling, index and } \\
\text { strength testing of soil samples. Sufficient } \\
\text { characterisation of foundation conditions for } \\
\text { the application of the observational method } \\
\text { to manage risk during spoil placement. } \\
\text { Instrumentation installations resulting in high } \\
\text { confidence models. }\end{array}$ \\
\hline $\begin{array}{l}\text { Spoils - assessment of spoil } \\
\text { performance from monitoring } \\
\text { data, and applying learning's } \\
\text { from monitoring when } \\
\text { planning and sequencing spoil } \\
\text { construction. }\end{array}$ & $\begin{array}{l}\text { How is monitoring data } \\
\text { used to fine tune our } \\
\text { designs? }\end{array}$ & $\begin{array}{l}\text { As required to 'provide a safe } \\
\text { work environment'. }\end{array}$ & $\begin{array}{l}\text { Ongoing, with learning's occasionally used } \\
\text { to optimise planning for future spoil } \\
\text { construction. }\end{array}$ & $\begin{array}{l}\text { Proactive, ongoing and with learning's always } \\
\text { applied to optimise the planning and } \\
\text { sequencing for future spoil construction. }\end{array}$ \\
\hline $\begin{array}{l}\text { Site infrastructure - } \\
\text { Geotechnical investigation } \\
\text { and design for new structures } \\
\text { and facilities. }\end{array}$ & $\begin{array}{l}\text { Do we involve geotechnical } \\
\text { personnel in the } \\
\text { construction and design } \\
\text { process? }\end{array}$ & $\begin{array}{l}\text { Regulatory requirements for } \\
\text { professional engineer to perform } \\
\text { design of structures and sign off } \\
\text { on building code schedules. }\end{array}$ & $\begin{array}{l}\text { Site geotechnical personnel consulted } \\
\text { during initial scoping and planning of } \\
\text { investigation and design, and provide input } \\
\text { based on knowledge and experience with } \\
\text { site conditions. }\end{array}$ & $\begin{array}{l}\text { Full attention to design and construction of } \\
\text { new structures and facilities by site } \\
\text { geotechnical personnel. Geotechnical Review } \\
\text { Board vetting if warranted based on the } \\
\text { significance of the new structure/facility. }\end{array}$ \\
\hline
\end{tabular}


Table 4 Excerpts from 'Operations and Monitoring' area of geotechnical practice table

\begin{tabular}{|c|c|c|c|c|}
\hline Element & Additional Context & $\begin{array}{l}\text { Regulatory Requirement or } \\
\text { Minimum Practice }\end{array}$ & Above Average & Industry Best Practice \\
\hline $\begin{array}{l}\text { Dewatering/depressurisation of pit } \\
\text { areas, sufficiently in advance of } \\
\text { mining and with linkage to } \\
\text { hydrogeological model. }\end{array}$ & $\begin{array}{l}\text { Are we monitoring the } \\
\text { implementation of the } \\
\text { dewatering plan in advance of } \\
\text { mining? }\end{array}$ & $\begin{array}{l}\text { Water management plans } \\
\text { based on conceptual work. }\end{array}$ & $\begin{array}{l}\text { Advance dewatering/ } \\
\text { depressurisation done occasionally } \\
\text { and usually designed based on } \\
\text { hydrogeological model. }\end{array}$ & $\begin{array}{l}\text { Consistently proactive dewatering/ } \\
\text { depressurisation based on hydrogeological } \\
\text { model, and targeted/optimised based on } \\
\text { ongoing reconciliation of the geotechnical } \\
\text { and hydrogeological models with actual } \\
\text { conditions as mining proceeds. }\end{array}$ \\
\hline $\begin{array}{l}\text { Monitoring program for pit wall } \\
\text { stability at bench/inter-ramp/wall } \\
\text { scale. }\end{array}$ & $\begin{array}{l}\text { How well do we monitor at } \\
\text { bench/inter-ramp/wall scale? }\end{array}$ & $\begin{array}{l}\text { Meeting minimum criteria } \\
\text { spelled out in operating licence. }\end{array}$ & $\begin{array}{l}\text { Consistent application, one or two } \\
\text { methods, occasional maintenance, } \\
\text { reasonably accurate and timely } \\
\text { data, properly reviewed and } \\
\text { interpreted. }\end{array}$ & $\begin{array}{l}\text { Proactive - consistent application, multiple } \\
\text { methods, robustly maintained, accurate and } \\
\text { timely data, promptly and properly reviewed } \\
\text { and interpreted. Critical monitoring systems } \\
\text { 'alarmed' to Dispatch for added redundancy } \\
\text { and enhanced response to emergencies. } \\
\text { Sharing of instability events/concerns to all } \\
\text { Teck Coal sites for group 'lessons learned'. }\end{array}$ \\
\hline $\begin{array}{l}\text { Blast vibration monitoring and } \\
\text { refinements to blast designs based } \\
\text { on operational experience, } \\
\text { monitoring and inspections of the } \\
\text { condition of as-mined slopes. }\end{array}$ & $\begin{array}{l}\text { Do we assess the impact of } \\
\text { blasting on wall stability? Do we } \\
\text { modify blast designs based on } \\
\text { the results of the analysis? }\end{array}$ & $\begin{array}{l}\text { Initial geotechnical } \\
\text { assumptions incorporated into } \\
\text { the blast design process. }\end{array}$ & $\begin{array}{l}\text { Blast designs occasionally refined, } \\
\text { but no system in place to routinely } \\
\text { assess blasting results and identify } \\
\text { the need to refine designs or an } \\
\text { opportunity to optimise blast } \\
\text { designs and save costs. }\end{array}$ & $\begin{array}{l}\text { Systematic review of blast designs in } \\
\text { conjunction with ongoing reconciliation of the } \\
\text { geotechnical model. Blast designs refined and } \\
\text { optimised based on steadily increasing } \\
\text { knowledge of rock and rock mass conditions } \\
\text { and experience base with blasting at site. }\end{array}$ \\
\hline $\begin{array}{l}\text { Geological and geotechnical } \\
\text { mapping of bench faces. }\end{array}$ & $\begin{array}{l}\text { Do we consistently map bench } \\
\text { faces to refine and update } \\
\text { geotechnical models? }\end{array}$ & $\mathrm{N} / \mathrm{A}$ & $\begin{array}{l}\text { Performance mapping completed } \\
\text { on highwalls and areas where } \\
\text { rockfall issues exist. } \\
\text { Recommendations and design } \\
\text { adjustments sometimes } \\
\text { completed. }\end{array}$ & $\begin{array}{l}\text { Performance mapping of all walls and } \\
\text { feedback into blasting and wall design } \\
\text { completed. }\end{array}$ \\
\hline $\begin{array}{l}\text { Pit wall performance assessment - } \\
\text { catchment. }\end{array}$ & $\begin{array}{l}\text { Do we capture final berm profiles } \\
\text { and reconcile to design to } \\
\text { understand how well operations } \\
\text { are developing the pit walls? }\end{array}$ & $\begin{array}{l}\text { No performance mapping } \\
\text { completed. }\end{array}$ & $\begin{array}{l}\text { Periodic surveys of some areas, } \\
\text { quarterly or annually reconciled } \\
\text { with production volumes and } \\
\text { checked against design. }\end{array}$ & $\begin{array}{l}\text { Periodic surveys of all areas using multiple } \\
\text { methods, monthly reconciliation with } \\
\text { production volumes and checked against } \\
\text { design and designs adjusted moving forward. }\end{array}$ \\
\hline
\end{tabular}


- Identification, investigation and assessments - proactive identification of geotechnical issues through investigation and assessment work.

- Procedures and Processes - for performing, managing and validating geotechnical work.

- Reconciliations - systems and activities to measure, track the implementation of designs and to revise and optimise designs based on actual conditions and performance.

This second set of radar plots provides an alternate perspective of the number and severity of gaps between the current and target levels of geotechnical practice.

\subsection{Categorisation and ranking of risks}

Items for which there is a gap between the current and target levels of geotechnical practice are compiled into a Risk Register where the most significant credible risk associated with each gap is recorded. The most significant, but credible, risks are used in order to have a reasonable level of conservatism in the Risk Register.

The identified risks are categorised by type of risk:

- Technical (i.e. reduced coal recovery).

- Cost.

- Schedule.

- Health and safety.

- Reputation.

- Legal/regulatory.

- Environment.

The categorised risks are then qualitatively ranked using the consequence and likelihood assessment scales and the Risk Ranking table from the Teck stage gating process for major projects, shown in Tables 5, 6 and 7. This ranking process was considered to be suitable and offered the advantage of using an established Teck process for risk management.

The resulting risk ranking values are grouped into ranges as follows:

- 1 to $5=$ 'low' (green).

- 6 to $13=$ 'moderate' (blue).

- 14 to 20 = 'high' (yellow).

- 21 to 25 = 'critical' (red).

It is important to note that the risk ranking values are not calculated by multiplying the likelihood and consequence rankings and that the risk ranking values are instead a qualitative ranking process. The use of numerical values in the process is only to facilitate ranking and does not represent a quantitative risk assessment.

\subsection{Results and recommended actions}

The ranked risks are reviewed to identify common themes, and then grouped by these themes. The grouped risks are then used as the basis to develop 'Project Initiatives' that list actionable steps for raising the level of geotechnical practice to the target levels and thus work towards mitigating the identified risks. 
Table 5 Consequence assessment scale

\begin{tabular}{|c|c|c|c|c|c|c|c|}
\hline Rating & Technical & Cost C\$C & Schedule & Health and Safety & Reputation & Legal/Regulatory & Environment \\
\hline 1-Minor & $\begin{array}{l}\text { Minor Difficulties, <1 } \\
\text { day production } \\
\text { interruption, }<1 \% \text { Rec. } \\
\text { loss }\end{array}$ & $\begin{array}{l}\text { Less than } \$ 1 \mathrm{M} \\
\text { capital or }<\$ 1 / \mathrm{t} \\
\text { operating cost } \\
\text { increase }\end{array}$ & $\begin{array}{l}<1 \\
\text { month } \\
\text { delay }\end{array}$ & $\begin{array}{l}\text { Minor injury, } \\
\text { near miss } \\
\text { incident. }\end{array}$ & $\begin{array}{l}\text { No media attention, } \\
\text { local issue, resolved } \\
\text { locally. }\end{array}$ & $\begin{array}{l}\text { Low level legal or } \\
\text { approval issue, } \\
\text { minor permit } \\
\text { revision. }\end{array}$ & $\begin{array}{l}\text { Non-reportable } \\
\text { impact, managed } \\
\text { within budget } \\
\text { and policy. }\end{array}$ \\
\hline 2-Moderate & $\begin{array}{l}\text { Can't achieve } 100 \% \\
\text { design without some } \\
\text { capital, two days } \\
\text { production loss, 1-2\% } \\
\text { Rec. loss }\end{array}$ & $\begin{array}{l}\$ 1 M-5 M \text { capital } \\
\text { or } \$ 1-2 / t \\
\text { operating cost } \\
\text { increase }\end{array}$ & $\begin{array}{l}1-3 \\
\text { months } \\
\text { delay }\end{array}$ & $\begin{array}{l}\text { Medical aid, } \\
\text { high potential } \\
\text { near miss, code } \\
\text { violation. }\end{array}$ & $\begin{array}{l}\text { Local media } \\
\text { attention, managed } \\
\text { locally. }\end{array}$ & $\begin{array}{l}\text { Minor breach of } \\
\text { regulation, letter } \\
\text { of variance, new } \\
\text { minor permit. }\end{array}$ & $\begin{array}{l}\text { Reportable } \\
\text { event, minor } \\
\text { clean-up and } \\
\text { remediation. }\end{array}$ \\
\hline 3 - Significant & $\begin{array}{l}\text { Can't achieve } 100 \% \\
\text { design without } \\
\text { significant capital, one } \\
\text { week production loss, } \\
\text { 2-5\% Rec. loss }\end{array}$ & $\begin{array}{l}\$ 5 \mathrm{M}-20 \mathrm{M} \\
\text { capital or } \$ 2-5 / \mathrm{t} \\
\text { operating cost } \\
\text { increase }\end{array}$ & $\begin{array}{l}3-6 \\
\text { months } \\
\text { delay }\end{array}$ & $\begin{array}{l}\text { Significant } \\
\text { injury, limited } \\
\text { lost time, } \\
\text { significant \& } \\
\text { serious violation } \\
\text { (S\&S). }\end{array}$ & $\begin{array}{l}\text { Local media } \\
\text { coverage, managed } \\
\text { by corporate. }\end{array}$ & $\begin{array}{l}\text { Serious breach, } \\
\text { investigation, } \\
\text { moderate fines, } \\
\text { major permit } \\
\text { revision. }\end{array}$ & $\begin{array}{l}\text { Event requiring } \\
\text { investigation and } \\
\text { minor } \\
\text { remediation, } \\
\text { short term } \\
\text { impairment. }\end{array}$ \\
\hline 4-Major & $\begin{array}{l}C \$ 20 M-50 \text { M capital } \\
\text { or } C \$ 10-20 / t \text { operating } \\
\text { cost increase }\end{array}$ & $\begin{array}{l}\text { \$20M-50M } \\
\text { capital or } \\
\$ 10-20 / t \\
\text { operating cost } \\
\text { increase }\end{array}$ & $\begin{array}{l}6-12 \\
\text { months } \\
\text { delay }\end{array}$ & $\begin{array}{l}\text { Serious injury, } \\
\text { significant lost } \\
\text { time, multiple } \\
\text { S\&S citations. }\end{array}$ & $\begin{array}{l}\text { National media } \\
\text { attention, public and } \\
\text { government } \\
\text { involvement. }\end{array}$ & $\begin{array}{l}\text { Major breach of } \\
\text { regulation, } \\
\text { litigation, serious } \\
\text { fines, new major } \\
\text { permit. }\end{array}$ & $\begin{array}{l}\text { Short term } \\
\text { damage, } \\
\text { significant } \\
\text { remediation, } \\
\text { minor penalties. }\end{array}$ \\
\hline 5 -Catastrophic & $\begin{array}{l}\text { Can't achieve } 60 \% \\
\text { design without } \\
\text { significant capital, >1 } \\
\text { month production loss, } \\
<10 \% \text { Rec. loss }\end{array}$ & $\begin{array}{l}>\$ 50 M \text { capital or } \\
>\$ 20 / \text { t operating } \\
\text { cost increase }\end{array}$ & $\begin{array}{l}>1 \\
\text { year } \\
\text { delay }\end{array}$ & $\begin{array}{l}\text { Fatality, multiple } \\
\text { LTI's, permanent } \\
\text { disability, cease } \\
\text { and desist order. }\end{array}$ & $\begin{array}{l}\text { National media } \\
\text { coverage, major } \\
\text { public engagement } \\
\text { and gov't } \\
\text { inquiry/action. }\end{array}$ & $\begin{array}{l}\text { Prosecution of } \\
\text { corporation and } \\
\text { individuals, class } \\
\text { action litigation. }\end{array}$ & $\begin{array}{l}\text { Long term } \\
\text { damage, major } \\
\text { remediation, } \\
\text { major penalties. }\end{array}$ \\
\hline
\end{tabular}




\section{Table 6 Likelihood assessment scale}

\begin{tabular}{|c|c|c|}
\hline Rating & Likelihood Description and Indicative Frequency & Probability \\
\hline 1 - Rare & $\begin{array}{l}\text { Very low likelihood but not impossible, unlikely to occur during the next } 40 \text { years. A similar event } \\
\text { has occurred elsewhere in this industry. }\end{array}$ & $<2 \%$ \\
\hline 2-Unlikely & $\begin{array}{l}\text { Plausible, unlikely to occur during the project, could occur over the next } 10 \text { to } 40 \text { years. A similar } \\
\text { event has occurred on other similar projects. }\end{array}$ & $2-10 \%$ \\
\hline 3-Moderate & $\begin{array}{l}\text { Possible, reasonable probability that it may occur at least once in a } 1 \text { to } 10 \text { year period. A similar } \\
\text { event has occurred at some time on other similar projects within the organisation. }\end{array}$ & $10-50 \%$ \\
\hline 4- Likely & $\begin{array}{l}\text { High probability, likely to occur approximately once per year. Similar event has occurred several } \\
\text { times per year on similar projects within the organisation. }\end{array}$ & $50-80 \%$ \\
\hline $5-$ Almost certain & $\begin{array}{l}\text { Very high probability of occurrence could occur several times per year. Has occurred several times } \\
\text { on similar projects at this location. }\end{array}$ & $>80 \%$ \\
\hline
\end{tabular}

\section{Table 7 Risk ranking table}

\begin{tabular}{|c|c|c|c|c|c|}
\hline & 1 - Minor & 2-Moderate & 3 - Significant & 4 - Major & 5-Catastrophic \\
\hline 1 - Rare & 1 (green) & 3 (green) & 6 (blue) & 10 (blue) & 15 (yellow) \\
\hline 2-Unlikely & 2 (green) & 5 (green) & 9 (blue) & 14 (yellow) & 19 (yellow) \\
\hline 3 -Moderate & 4 (green) & 8 (blue) & 13 (blue) & 18 (yellow) & 22 (red) \\
\hline 4-Likely & 7 (blue) & 12 (blue) & 17 (yellow) & 21 (red) & 24 (red) \\
\hline 5 - Almost certain & 11 (blue) & 16 (yellow) & 20 (yellow) & 23 (red) & 25 (red) \\
\hline
\end{tabular}




\section{2 implementation}

The Geotechnical Assessment Process was implemented at the operating sites during Q2 and Q3 2012 through on-site meetings with site personnel.

Each site session was facilitated by a senior geotechnical engineer and senior mining engineer from Teck Coal's corporate engineering group. Each site's geotechnical personnel attended their entire site session and other site personnel (e.g. Superintendent Engineering, short and long range mine planners, modelling and exploration geologists, drill and blast engineers) participated in the parts of the site sessions where the areas of geotechnical practice relevant to their roles were discussed. The sequence for each site session was as follows:

1. The facilitators presented an overview of the purpose, objectives and procedures for the Geotechnical Assessment Process at the start of each site session.

2. The facilitators and site personnel then worked through the assessment tool. The site personnel provided the primary inputs for selecting the current and target levels of geotechnical practice for each of the technical elements for the five areas of geotechnical practice. The facilitators provided advice on selecting current and target levels of practice as appropriate to maintain reasonable inter-site consistency in the level of rigor of each sites' self-evaluation and in the context of establishing corporate standards for the target levels of practice.

3. The facilitators then categorised and ranked the identified geotechnical risks, compiled the results into a geotechnical Risk Register and prepared a first draft of the Project Initiatives.

4. The facilitators then presented the draft Project Initiatives to the Superintendent Engineering and site geotechnical personnel, followed by a round-table discussion and initial feedback from the site personnel to close-out the site session.

Shortly after each site session, the facilitators incorporated the feedback from the closing discussion with the site personnel into the draft current and target level of practice rankings on the 'Area of Geotechnical Practice' tables, the Risk Register and Project Initiatives. The draft versions of these items were then circulated back to the site geotechnical personnel and Superintendent Engineering for their review before they were finalised.

\section{2 results and recommended actions}

Table 8 lists the titles of the seven Project Initiatives were developed based on common themes identified in the ranked risks for each site. The specifics of the recommended actions for each of the Project Initiatives varied between the sites as appropriate based on the site-specific geotechnical risks that were identified.

A summary report was then prepared to compile all of the site results and Project Initiatives, and also to present strategic geotechnical recommendations for Teck Coal based on an overall review and assessment of the results of the Geotechnical Assessment Process from the operating sites. This summary report was finalised in Q4 2012 and circulated to the engineering departments at each site along with Teck Coal's senior management.

\section{$7 \quad$ Summary and path forward}

The Geotechnical Assessment Process is the start of a sustained effort to standardise the application of best practices to the identification, assessment and management of geotechnical risk at Teck Coal's operating sites and development projects. The key strength of the Geotechnical Assessment Process is that it provides a consistent and repeatable method to identify and rank risks for the geotechnical aspects of the design, operations and closure at a variety of mine sites. This is of particular value for Teck Coal's sites, which vary significantly in size (ranging between approximately 2.0 and 9.5 million tonnes of clean coal produced annually) and remaining mine life (ranging from less than 10 years to greater than 50 years) in 
addition to having varying degrees of legacy geotechnical issues due to past engineering and operating practices.

In the near-term, each of Teck Coal's operating sites will incorporate the prioritised action items from the Geotechnical Assessment Process into their annual planning and budgeting processes. The results of the Geotechnical Assessment Process will typically provide the business case for adding geotechnical staff, higher levels of proactive geotechnical investigation, assessment and monitoring, and more effective engagement of external geotechnical consultants.

In the medium-term, Teck Coal's corporate engineering group will perform periodic geotechnical audits at the operating sites to follow-up on the 2012 Geotechnical Assessment Process. The Geotechnical Assessment Process will also be applied to future development projects in order to establish a high level of geotechnical practice early in each project's life cycle.

\section{Table 8 Project initiatives from assessment process}

\begin{tabular}{ll}
\hline Project Initiative Title & Lead Party for Implementation \\
\hline $\begin{array}{l}\text { Human resourcing } \\
\begin{array}{l}\text { Proactive geotechnical investigation and design } \\
\text { work }\end{array}\end{array}$ & $\begin{array}{l}\text { Implementation to be led at site level } \\
\text { Implementation to be led at site level }\end{array}$ \\
$\begin{array}{l}\text { Improving geotechnical monitoring capability } \\
\text { Geotechnical systems improvement }\end{array}$ & $\begin{array}{l}\text { Implementation to be led at site level } \\
\text { Implementation to be led at site level }\end{array}$ \\
$\begin{array}{ll}\text { Developing ground control management plans } \\
\text { Implementation to be started by the corporate } \\
\text { engineering group, followed by roll-out and } \\
\text { collaboration with the sites for final implementation }\end{array}$ \\
$\begin{array}{ll}\text { Implementation to be started by the corporate } \\
\text { engineering group, followed by roll-out and } \\
\text { collaboration with the sites for final implementation }\end{array}$ \\
$\begin{array}{l}\text { Implementation to be started by the corporate } \\
\text { Commung development of a geotechnical }\end{array}$ & $\begin{array}{l}\text { engineering group, followed by roll-out and } \\
\text { collaboration with the sites for final implementation }\end{array}$ \\
\hline
\end{tabular}

\section{Acknowledgement}

Teck Coal acknowledges the valuable input that four external reviewers provided to the development of the Geotechnical Assessment Process - Al Chance (Golder Associates), Michael Davies (formerly of AMEC, now Teck Resources Ltd), Pete Stacey (Stacey Mining Geotechnical Ltd) and Al Stewart (Piteau Associates).

\section{References}

British Columbia Mine Waste Rock Pile Research Committee, 1991 Mined Rock and Overburden Piles Investigation and Design Manual Interim Guidelines

Dixon, R.A., Johnson, T.M., de Graaf, P.J.H., Wessels, S.D.N. and Venter, J. (2011) Risk based geotechnical slope reconciliation at Rio Tinto Iron Ore, Pilbara Operations, in Proceedings International Symposium on Rock Slope Stability in Open Pit Mining and Civil Engineering (Slope Stability 2011), E. Eberhardt and D. Stead (eds), 18-21 September 2011, Vancouver, Canada, Canadian Rock Mechanics Association, Canada, CD-rom only.

Eaton, T. (2000) Operation and monitoring considerations from a British Columbia mountain terrain perspective, in Slope Stability in Surface Mining, W.A. Hustrulid, M.K. McCarter and D.J.A. Van Zyl (eds), Society for Mining, Metallurgy, and Exploration, pp. 311-321.

Hamman, E.C.F. (2009) Qualitative geotechnical hazard and risk assessment, in Proceedings International Symposium on Rock Slope Stability in Open Pit Mining and Civil Engineering (Slope Stability 2009), 9-11 November 2009, Santiago, Chile, CD-rom only.

Stacey, P. (2009) Fundamentals of slope design, in Guidelines for Open Pit Slope Design, J. Read and P. Stacey (eds), CRC Press/Balkema, Rotterdam, pp. 1-14. 